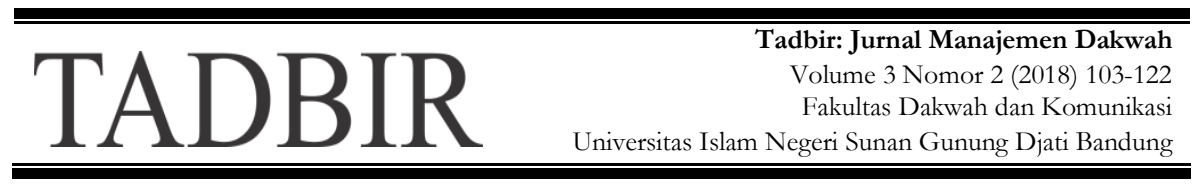

\title{
Manajemen Komunikasi Pengelola Zakat Melalui Strategi Human Resources Development
}

\author{
Lina Yulianti ${ }^{1}$ \\ 1Universitas Islam Negeri Sunan Gunung Djati, Bandung \\ lina_sabira@yahoo.co.id
}

\begin{abstract}
ABSTRAK
Penelitian ini bertujuan untuk menganalisis proses manajemen komunikasi pengelola UPZ MD yang ditinjau dari penerapan strategi Human Resources Development (HRD). Manajemen komunikasi tersebut baik secara verbal maupun non verbal yang meliputi aspek informing, persuading dan collaborating. Penelitian ini merupakan penelitian kualitatif deskriptif. Dimana penelitian ini berupaya untuk menganalisis penerapan manajemen komunikasi melalui strategi HRD. Pengumpulan data dilakukan melalui wawancara dan observasi. Wawancara melibatkan informan utama baik dari jurusan Manajemen Dakwah, Dosen tetap yang ditunjuk sebagai pengelola dan mahasiswa sebagai pelaksana teknis UPZ. Hasil penelitian menunjukkan bahwa manajemen komunikasi pengelola zakat UPZ MD dilakukan baik secara verbal maupun non verbal. Komunikasi verbal dalam bentuk lisan misalnya pada saat rapat rutin, sedangkan dalam bentuk tulisan misalnya melalui penyusunan laporan, SOP, dan lembar sumbang saran. Komunikasi non verbal dilaksanakan pada saat pelayanan terhadap pengguna yang diwujudkan dalam bentuk prinsip kerja yang tertera dalam SOP dan maklumat pelayanan prima UPZ MD. Penerapan strategi Human Resources Development (HRD) UPZ MD terdapat dalam tiga aspek yakni aspek informing (misalnya rapat rutin, FGD Pengurus, Seminar dan Lokakarya); persuading (Sosialisasi brand image UPZ melalui media komunikasi langsung dan digital serta penyusunan program UPZ MD); dan collaborating (dalam bentuk pembagian kerja yang dibuktikan adanya SOP Pengelolaan UPZ dan Struktur Organisasi).
\end{abstract}

\section{Kata Kunci : Manajemen Komunikasi, UPZ MD, Strategi HRD}

\section{ABSTRACT}

This study aims to analyze the communication management process of UPZ MD managers in terms of the implementation of the Human Resources Development (HRD) strategy. Communication management is both verbal and non-verbal which includes aspects of 
informing, persuading and collaborating. This research is a descriptive qualitative research. Where this study seeks to analyze the application of communication management through HRD strategies. Data collection is done through interviews and observations. The interview involved key informants from the Da'wah Management Department, permanent lecturers appointed as managers and students as UPZ technical implementers. The results showed that the management of UPZ MD's zakat management was done both verbally and non-verbally. $V$ erbal communication in oral form for example during routine meetings, while in written form for example through the preparation of reports, SOPs, and suggestion sheets. Non-verbal communication is carried out at the time of service to users which is manifested in the form of work principles stated in the SOP and UPZ MD excellent service notice. The implementation of UPZ MD's Human Resources Development (HRD) strategy consists of three aspects, namely the informing aspect (for example, regular meetings, FGD Management, Seminars and Workshops); persuading (UPZ brand image socialization through direct and digital communication media and preparation of the UPZ MD program); and collaborating (in the form of division of labor as evidenced by the UPZ Management SOP and Organizational Structure).

Keywords: Communication Management, UPZ MD, HRD Strategy

\section{PENDAHULUAN}

Kebutuhan manusia terhadap pemenuhan hasrat biologis mengantarkan dirinya untuk terus berkreasi dalam mempertahankan hidup. Dalam hal ini, kebutuhan biologis dapat kita artikan sebagai segala sesuatu yang diperlukan manusia untuk memenuhi keinginan pokok berupa sangan, pangan dan papan. Yakni, kebutuhan yang bersifat primer seperti makanan, sekunder dan tersier seperti rekreasi. Pada posisinya, pemenuhan kebutuhan ini terus dilakukan sebagai wujud pemenuhan standar dasariah manusia yang tidak bisa dihilangkan.

Manusia sadar bahwa kehidupan yang dijalaninya dalam rangka memenuhi segala kebutuhan biologisnya tidak bisa dilakukan seorang diri. Secara praktis manusia memerlukan manusia lain, bahkan makhluk lain untuk memenuhi hasrat atau kebutuhan biologis tersebut. Maka, terwujudlah interaksi atau hubungan antar manusia. Jika ditinjau dari aspek sosiologis, maka interaksi yang terjalin diantara manusia bukan tanpa kepentingan pragmatis. Ada tujuan yang ingin dicapai oleh setiap manusia dalam menjalankan fungsi dan peran sosialnya. Peran dan fungsi tersebut merupakan wujud relasional manusia secara sosial dalam menjalankan peran dirinya sebagai makhluk komunikasi yang selalu melaksanakan bisnis dengan yang lainnya.

Kesuksesan sebuah perusahaan sangat tergantung pada bagaimana perusahaan memposisikan pegawai dan pelanggannya sebagai sumber daya kekuatan yang dapat mengembangkan tujuannya. Pengembangan sumber daya 
manusia sebagai kekuatan utama perusahaan dapat dilakukan melalui integrasi konsep internal communication dan internal marketing perusahaan yang mengandalkan pegawai dan pelanggan sebagai promotion and propaganda core dari perusahaan.

Pada posisinya, fungsi ini lakukan untuk mencapai tujuan perusahaan.Berupa pengembangan SDM, penyebaran informasi perusahaan, membangun brand image, promosi produk perusahaan, propaganda nilai, karakteristik, dan tujuan perusahaan, serta persebaran keuntungan perusahaan. Dalam konteks komunikasi bisnis, hal tersebut merupakan tiga tujuan komunikasi bisnis. Yakni, informing, persuading, dan collaborating. Salah satu lembaga yang memiliki tingkat kepercayaan di masyarakat adalah lembaga zakat. Kemunculan lembaga filantropi Islam seperti Rumah Zakat, Dompet Dhuafa, Sinergi Foundation, DPU-DT, dan lain-lain merupakan fenomena populer dalam proses penghimpunan dana zakat, infaq dan shodaqoh di masyarakat. Secara profesional, lembaga ini dapat dikelola menggunakan prinsip-prinsip perusahaan profit sebagaimana layaknya. Namun, yang membedakan adalah kedudukan lembaga zakat sebagai organisasi nirlaba yang membantu proses ritualistik ibadah umat Islam dalam menyalurkan dana ZIS.

Di Indonesia, permasalahan mengenai pengelolaan lembaga zakat secara profesional adalah isu yang sangat penting, karena penghimpunan zakat memiliki potensi besar dalam menyejahterakan umat (Rahim \& Syahrullah, 2017: 200). Hal ini berkaitan dengan proses penghimpunan, pendayagunaan, pendistribusian, penghitungan dan pemberdayaan dana ZIS yang produktif dan berkesinambungan. Keberadaan lembaga filantropi Islam di Indonesia menjadi wujud bagaimana peran dan potensi zakat mampu membangkitkan ekonomi umat Islam. Hal ini mendorong adanya pengelolaan lembaga zakat yang profesional sebagaimana layaknya pengelolaan terhadap sebuah lembaga ekonomi.

Secara teknis, lembaga pemerintah penghimpun zakat dikenal dengan BAZNAS (Badan Amil Zakat Nasional) yang tersebar di seluruh provinsi, Kabupaten dan Kota. Secara keorganisasian, untuk menghimpul dana BAZNAS memiliki kewenangan untuk membentuk Unit Pengumpul Zakat (UPZ) dan Lembaga Amil Zakat (LAZ). UPZ dan LAZ ini tersebar di seluruh pelosok Indonesia. salah satu model pendirian UPZ adalah unit pengumpul zakat yang berbasis masjid dan berbasis kampus. Salah satu UPZ yang berbasis kampus adalah UPZ Manajemen Dakwah yang menjadi salah satu UPZ di Jurusan Manajemen Dakwah (MD) Fakultas Dakwah dan Komunikasi UIN Sunan Gunung Djati Bandung. Dalam hal ini, UPZ MD memiliki kedudukan ganda, yakni sebagai UPZ di tingkat kampus yang memiliki legalitas dari BAZNAS dan 
sebagai laboratorium praktik mahasiswa MD mengenai manajemen ZIS.

Untuk menghasilkan tenaga profesional di bidang manajemen dakwah (tadbir) diperlukan berbagai upaya untuk menguasai bidang kajian ilmu dakwah, hubungan kajian teori dengan praktik manajemen dakwah, serta menghasilkan produk yang berbasis pada media pembelajaran kontekstual. Salah satu yang dipandang penting dalam penyelenggaran layanan pendidikan di Program Studi adalah ketersediaannya laboratorium. Hal ini sebagai sarana yang mampu menjembatani antara kajian teoritik dengan praktik bagi pengguna layanan pendidikan tersebut (Budiata \& Lasia, 2014).

Program Studi Manajemen Dakwah berorientasi menjadi program studi yang unggul dan inovatif dalam bidang manajemen dakwah (tadbir) di Asia Tenggara pada tahun 2025. Visi tersebut kemudian diturunkan ke dalam misi dan tujuan program studi yang mengacu pada rencana strategis (renstra) dan rencana operasional (renop) program studi, untuk kemudian diaktualisasikan ke dalam berbagai penyelenggaraan dan pelayanan pendidikan.

Dalam perkembangannya, Program Studi Manajemen Dakwah memiliki 3 (tiga) laboratorium yang dapat dijadikan sebagai sarana bagi aktualisasi mahasiswa manajemen dakwah secara kontekstual. Ketiga laboratorium tersebut didirikan dengan memperhatikan core keilmuan atau kelompok kerja profesi (KKP) yang meliputi delapan kompetensi utama Program Studi MD, diantaranya a) pengelolaan majelis taklim, b) pengelolaan masjid, c) pengelolaan organisasi kemasyarakatan Islam, d) pengelolaan organisasi politik Islam, e) pengelolaan pelaksanaan ibadah haji, umrah dan ziarah, f) pengelolaan zakat, g) pengelolaan Lembaga swadaya masyarakat (LSM) dakwah, dan h) pengelolaan Lembaga keuangan Islam.

Penelitian seputar manajemen komunikasi pernah dilakukan sebelumnya, antara lain penelitian tentang strategi komunikasi pengelola ZIS melalui Media Sosial (Herman, 2017). Hasil penelitian menunjukkan bahwa strategi komunikasi lembaga zakat DPU DT yang dilakukan melelui media sosial terbukti efektif dan menghimpun dana pada September 2017 sampai 8,44 Miliar Rupiah. Penelitian tentang manajemen sumber daya insani di BAZNAS Ponorogo (Saputro \& Rois, 2017). Hasil penelitian menunjukkan bahwa pemetaan manajemen sumber daya insani di BAZNAS Ponorogo di mulai dari proses rekruitmen, penempatan, manajemen komunikasi dan evaluasi. Penelitian tentang kontekstualisasi pengelolaan zakat (Rosadi, 2015). Hasil penelitian menunjukkan bahwa kesuksesan pengelolaan zakat ditentukan oleh tiga aspek yakni substansi, struktur dan kultur.

Selain itu, penelitian seputar Human Resources Development (HRD) pernah dilakukan sebelumnya. Penelitian tentang strategi komunikasi persuasif dalam 
penyelesaian konflik (Anaomi, 2014). Hasil penelitian menunjukkan bahwa konflik terjadi ketika adanya proses komunikasi yang tersendat. Komunikasi persuasif dalam tinjauan buman resources leadership development memberikan efek positif dalam melerai konflik dan meningkatkan budaya positif di perusahaan. Penelitian tentang Human Resources Development berdasarkan kompetensi (Jihad, 2010). Hasil penelitian menujukkan bahwa melalui HRD proses penempatan sumber daya manusia dapat sejalan dengan visi perusahaan. Dimana keberadaan pemimpin yang memahami kondisi perusahaan, karyawan yang memiliki tingkat kepedulian dan tanggung jawab terhadap kewajiban serta manajemen komunikasi yang efektif dan efisien adalah wujud kompetensi HRD dalam mencapai tujuan organisasi. Penelitian tentang urgensi dan strategi promosi Unit Pengumpul Zakat Masjid (Kamal, 2016). Hasil penelitian menunjukkan bahwa strategi pengumpulan zakat di Provinsi Aceh (fundrising) dilakukan melalui penerapan strategi yang berorientasi pada buman resources management yang dilakukan melalui aplikasi promosi, sosialisasi dan pengaktifkan UPZM.

Tulisan ini berupaya menganalisis proses manajemen komunikasi pengelola UPZ MD yang ditinjau dari penerapan strategi Human Resources Development (HRD). Manajemen komunikasi tersebut baik secara verbal maupun non verbal yang meliputi aspek informing, persuading dan collaborating. Penelitian ini merupakan penelitian kualitatif deskriptif. Dimana penelitian ini berupaya untuk menganalisis penerapan manajemen komunikasi melalui strategi HRD. Pengumpulan data dilakukan melalui wawancara dan observasi. Wawancara melibatkan informan utama baik dari jurusan Manajemen Dakwah, Dosen tetap yang ditunjuk sebagai pengelola dan mahasiswa sebagai pelaksana teknis UPZ. Analisis data dilakukan dengan menguraikan data hasil penelitian yang dipandang relevan dengan konteks penelitian. Analisis data didapatkan melalui proses wawancara dan observasi berkaitan dengan manajemen komunikasi, pengelolaan UPZ dan penerapan strategi HRD sebagaimana tujuan dan lingkup penelitian.

\section{LANDASAN TEORITIS}

\section{Definisi Komunikasi Manajemen}

Komunikasi manajemen adalah komunikasi yang digunakan dalam dunia manajemen yang mencakup berbagai macam bentuk komunikasi baik komunikasi verbal maupun nonverbal. Komunikasi manajemen berbeda dengan komunikasi antar pribadi maupun komunikasi lintas budaya. Komunikasi antar pribadi (interpersonal communications) merupakan bentuk komunikasi yang lazim dijumpai dalam kehidupan sehari-hari antara dua orang atau lebih untuk mencapai tujuan tertentu.Sedangkan komunikasi lintas budaya (intercultural 
communication) merupakan bentuk komunikasi yang dilakukan antara dua orang atau lebih, yang masing-masing memiliki budaya yang berbeda.

Komunikasi manajemen adalah setiap komunikasi yang digunakan untuk membangun partnerships, sumber daya intelektual, untuk mempromosikan satu gagasan; suatu produk; servis; atau suatu organisasi, dengan sasaran untuk menciptakan nilai bagi manajemen yang dijalankan. Komunikasi Manajemen meliputi pengetahuan yang menyeluruh dari sisi internal dan eksternal manajemen tersebut. Komunikasi yang internal termasuk komunikasi visi (perseroan/perusahaan), strategi, rencana-rencana, kultur/budaya perusahaan, nilai-nilai dan prinsip dasar yang terdapat di perusahaan, motivasi karyawan, serta gagasan-gagasan, dll. Komunikasi eksternal termasuk merek, pemasaran, iklan, hubungan pelanggan, humas, hubungan-hubungan media, negosiasi-negosiasi manajemen, dll. Bagaimanapun bentuknya, semua hal tersebut memiliki tujuan yang sama, yaitu menciptakan suatu nilai manajemen (create business value).

Komunikasi manajemen digunakan untuk menyatakan gagasan (how to express ideas) dan menyebarkan gagasan (how to share ideas) tentang manajemen. Prinsip utama dalam komunikasi manajemen ialah bagaimana terciptanya hubungan yang simultan, saling memahami, dan untuk menyamakan persepsi antar partisipan komunikasi. Sebab orientasi manajemen adalah mendapatkan keuntungan, maka komunikasi manajemen dilakukan dalam rangka mendukung proses perniagaan, perdagangan atau manajemen yang terjalin. Dengan begitu, setiap partisipan komunikasi yang terlibat dalam kegiatan manajemen harus memiliki kemampuan komunikasi (Communication Skills). Kemampuan komunikasi ini digunakan untuk meningkatkan daya saing dan kemampuan memahami pasar. Sehingga, produk yang dihasilkan oleh sebuah perusahaan memiliki brand image di masyarakat, dapat menarik minat pelanggan, serta mendatangkan keuntungan (profitable) (Mery Ellen Gufey \& Dana Loewy, 2013:2)

\section{Tujuan Komunikasi Manajemen}

Setidaknya, terdapat tiga tujuan komunikasi manajemen yakni: memberikan informasi (informing) mengenai penyajian data perusahaan untuk pihak internal ataupun eksternal, melakukan persuasi atau bujukan (persuading) terutama kepada para pelanggan dengan harapan meningkatkan minat dan memperluas jaringan, serta melakukan kolaborasi (collaborating) dengan pihakpihak tertentu yang dipandang penting dan mampu meningkatkan daya saing perusahaan (Djoko Purwanto, dalam Muhammad Rizka, 2013:3). Dalam konteks komunikasi manajemen, tujuan tersebut dapat dicapai melalui personal communication (komunikasi lisan seperti negosiasi) dan written communication (komunikasi tertulis seperti pembuatan surat niaga, memorandum, dll).

Keberhasilan komunikasi manajemen juga sangat ditentukan oleh adanya 
efektivitas dalam komunikasi manajemen (Djoko Purwanto, dalam Rizka, 2013). Efektivitas komunikasi manajemen ditentukan oleh: Pertama, persepsi komunikator dalam memprediksi tingkat penerimaan pesan oleh komunikan. Kedua, penggunaan dan pemilihan media yang tepat sebagai saluran pesan komunikasi. Ketiga, ketepatan audiens yang dilihat dari kerangka berfikir dan pengalaman. Keempat, kredibilitas antara komunikator dan komunikan dalam menciptakan lingkungan komunikasi yang mendukung. Kelima, pengendalian komunikator dapat menjaga hubungan persahabatan yang menyenangkan dengan komunikan. Keenam, kecocokan komunikasi yang dapat memberikan reaksi/umpan balik/feedback terhadap pesan yang disampaikan.

\section{Human Resources Development}

Konsep Human Resources Mnagement (HRD) dalam sebuah perusahaan mulai berkembang pada tahun 1900-an. Penyusunan konsep HRD ini mulai serius dipikirkan pada tahun 1980-an. Konsep dasar dari pengembangan HRD adalah bagaimana memberikan pengetahuan yang memadai, membangkitkan semangat atau motivasi pegawai serta penjelasan mengenai konsep kesehatan dan intelektualitas pegawai sebagai basis kekuatan perusahaan. Hal ini diasumsikan bahwa modal terbesar sebuah perusahaan adalah modal ekonomi, namun yang lebih penting adalah modal pengetahuan yang dimiliki pegawainya. Maka, sejak saat itulah, HRD terus dikembangkan dalam rangka mencapai kesuksesan sebuah perusahaan (Preffer, dalam Dubravka, 2007: 7).

Secara sederhana, Human Resources Development dapat diartikan sebagai sebuah proses perekrutan, pelatihan, pendidikan pegawai yang dilakuan oleh sebuah perusahaan untuk memberikan pemahaman mengenai informasi perusahaan kepada pegawai sehingga pegawai memahami tugas dan peran tanggung jawabnya. HRD pun bisa diartikan sebagai sebuah strategi komprehensif dalam sebuah pengelolaan organisasi perusahaan (Setiawan, 2012: 351). Tujuannya adalah menciptakan kualitas dan kredibilitas pegawai yang memiliki kecerdasan holistik.

Menurut Hall dan Goodale (1998, dalam Dubravka, 2007:8) terdapat empat komponen utama dalam konteks pelaksanaan HRD, yakni: pemerintah, perusahaan, pekerjaan dan pegawai. Keempat komponen HRD ini sangat menentukan kesuksesan sebuah perusahaan dalam mencapai tujuannya. Adapun tujuan HRD menurut Armstrong (1999) ialah: 1) untuk meningkatkan pemahaman pegawai mengenai tujuan perusahaan yang harus dicapai sebagai tanggung jawab bersama. 2) untuk membangkitkan kemampuan, komitmen dan motivasi pegawai. 3) untuk meningkatkan kapasitas pegawai. 4) menciptakan 
iklim produktif dan hubungan harmonis antara manajemen dan pegawai. 5) untuk membentuk teamwork dalam sebuah perusahaan. 6) membantu perusahaan dalam membagi performa kerja pegawai.

McLagan (1989) sebagaimana dijelaskan Khatijatusshalihah (2016: 361) menjelaskan bahwa terdapat tiga domain utama dalam HRD yakni pengembangan organisasi, pelatihan dan pembinaan individu dalam organisasi dan manajemen karir. Fungsi HRD itu sendiri ialah sebagai sarana untuk mengembangkan SDM, merencanakan rencana kerja, analisa pekerjaan, penciptaan budaya dan iklim perusahaan, pemahaman tentang kerja sehat, aman dan cerdas, rekruitmen dan seleksi, pelatihan dan pengembangan, dan untuk meningkatkan hubungan dengan pegawai serta pelayanan kerja pegawai.

\section{HASIL DAN PEMBAHASAN}

\section{Manajemen Komunikasi Unit Pengumpul Zakat Manajemen Dakwah}

HRD merupakan salah satu strategi perusahaan yang memiliki fungsi yang variatif. Selain memang diorientasikan untuk mengembangkan kapasitas, kualitas dan kredibilats pegawai, HRD digunakan sebagai strategi untuk merumuskan manajerial perusahaan, membagi wilayah kerja dan meningkatkan performa perusahaan dalam rangka mencapai tujuan yang diinginkan.

HRD mempunyai orientasi dalam mencapai tujuan komunikasi bisnis, yakni: pertama, strategi HRD dapat dilakukan dalam rangka melaksanakan tujuan informing perusahaan. Peningkatan kapsitas pegawai dari tahapan rekrutmen, seleksi dan penetapan kerja merupakan proses yang dilakukan untuk memilih pegawai agar memiliki kemampuan yang diinginkan perusahaan, sekaligus perusahaan memberikan informasi mengenai tujuan, sistem, strategi, pelayanan dan budaya perusahaan kepada pegawai. Kedua, tujuan persuading. Ialah bahwa perusahaan melakukan diseminasi mengenai informasi produk perusahaan. Ketika HRD melaksanakan tugas perekrutan dan pelatihan pegawai, ada titik penekanan mengenai apa yang harus dilakukan pegawai dalam rangka menyebarkan produk perusahaan, propaganda brand image perusahaan, promosi perusahaan, dan lain-lain. Dan ketiga, tahapan collaborating. Bahwa melalui rekrutmen, seleksi, pelatihan, pembagian manajerial, penciptaan iklim dan budaya kerja, menjelaskan bahwa perusahaan telah melakukan tujuan kolaborasi. Salah satu fungsi HRD adalah untuk membentuk teamwork yang bisa diandalkan perusahaan. Teamwork akan terwujud ketika telah dilakukan analisis kerja dan pembagian wilayah kerja. Artinya, dilakukan melalui kolaborasi potensi dan kekuatan perusahaan agar tujuan perusahaan tercapai (Setiawan, 2015: 353).

Secara umum, kualitas manajemen komunikasi sumber daya pengelola zakat masih terbilang rendah. Hal ini disebabkan masih memandang pengelola 
zakat tidak secara profesional, melainkan masih dianggap sebagai kerja sampingan atau pekerjaan paruh waktu sehingga berdampak pada proses penghimpunan (Huda \& Sawarjuwono, 2013: 377). Padahal kalau ditinjau dari strategi HRD sebagaimana dijelaskan di atas, pengelolaan zakat baik oleh lembaga zakat pemerintah maupun swasta harus berorientasi pada pengelolaan profesional, dimana penghimpunan, pendayagunaan, pendistribusian dan pemberdayaan dilakukan secara profesional. HRD melihat bahwa upaya profesionalitas tersebut dilakukan melalui perumusan dan perencanaan, pembentukan teamwork, penetapan tujuan organisasi, proses operasionalisasi yang inovatif, efektif dan efisien, monitoring dan evaluasi secara berkala dan berkesinambungan, serta manajemen komunikasi yang berorientasi pada pemahaman visi organisasi secara merata. Manajemen komunikasi pada dasarnya dilakukan untuk mencapai pelayanan optimal dan kepuasaan pelanggan atau pengguna (Sosiawan, 2009: 72).

Selanjutnya, pencapaian ini dapat dilakukan tergantung pada efektifitas komunikasi yang dilakukan perusahaan dan pegawai. Setidaknya ada dua bentuk komunikasi yang umum digunakan dalam dunia bisnis,yaitu:

\section{Komunikasi verbal Pengelola UPZ MD}

Kadang dalam prakteknya, di dalam suatu komunikasi bisnis terjadi penggabungan antar komunikasi verbal dan komunikasi nonverbal dalam suatu situasi. Karena biasanya kata-kata yang disampaikan dalam suatu komunikasi atau percakapan kadang hanya membawa sebagian dari pesan. Dan relevansinya dalam komunikasi bisnis, tipe komunikasi nonverbal dapat menentukan kredibilitas dan kepemimpinan seseorang, yang dapat dilihat dari karateristik suara, penampilan, sentuhan, gerakan dan posisi tubuh juga melalui ekspresi wajah dan mata.

Sedangkan komunikasi verbal memilki tipe yang dibedakan menjadi dua yaitu, berdasarkan aktif atau pasifnya peserta komunikasi dalam proses komunikasi. Dimana komunikasi verbal dapat bertindak sebagai komunikator atau pengirim pesan dan dapat bertindak sebagai audience. Adapun dalam berkomunikasi secara verbal, dibutuhkan pengungkapan kata-kata yang disusun dalam suatu pola yang berarti, baik dalam bentuk tulisan maupun lisan, seperti: 1). Berbicara dan Menulis, suatu pesan yang sangat penting dan kompleks, sebaiknya disampaikan dengan menggunakan tulisan, seperti surat, memo dan laporan. 2). Mendengarkan dan Membaca, untuk mencapai komunikasi yang efektif, maka diperlukan komunikasi dua arah, dimana orang-orang yang terlibat di dalamnya memerlukan ketrampilan mendengar (listening) dan membaca 
L. Yulianti

(reading).

Dalam konteks komunikasi verbal, UPZ MD melakukan beberapa proses komunikasi. Antara lain, melalui perumusan SOP, Sumbang Saran, FGD, Sosialisasi UPZ dan Program-program pengelolaan baik dalam bentuk penghimpunan, pendayagunaan dan pendistribusiaan. Komunikasi verbal ini dilakukan baik untuk internal pengelola maupun untuk eksternal (user) di lingkungan jurusan Manajemen Dakwah. Komunikasi verbalistik ini dilakukan melalui beragam media komunikasi baik lisan maupun tulisan. Misalnya, adanya kotak saran dan lembar evaluasi atau sumbang saran merupakan wujud komunikasi verbal dua arah antara pengelola dan pengguna (dalam hal ini muzakki maupun mustahiq). Selain itu, alur komunikasi dibuktikan juga dengan adanya alur pengelolaan dan struktur organisasi pengelola.

Gambar 1. Proses Komunikasi Verbal UPZ MD
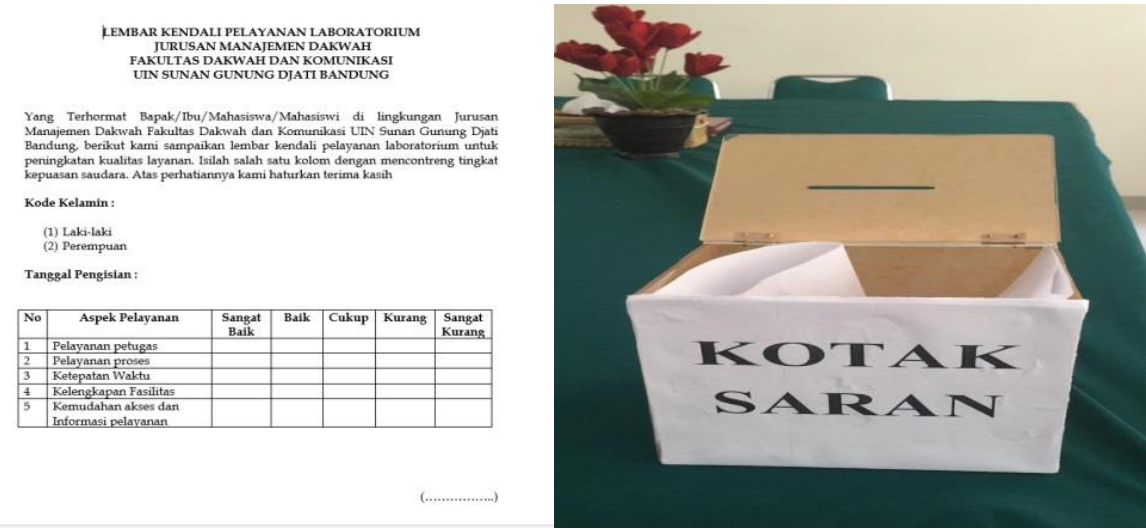

Sumber : UPZ MD, 2018

Gambar 2. Alur Komunikasi UPZ MD

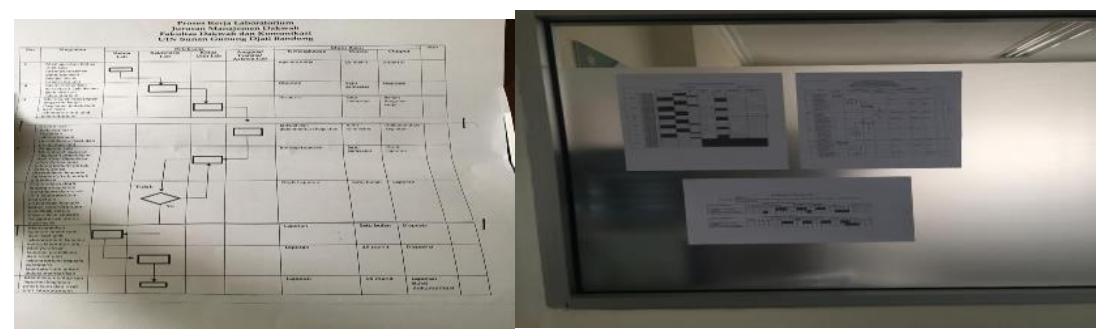

Sumber : UPZ MD, 2018

Gambar 1 merupakan proses komunikasi verbal dua arah antara pengguna dan pengelola. Gambar 2 adalah alur pelayanan atau pengelolaan UPZ MD dari 
hulu sampai hilir. Dari mulai perencanaan, penghimpunan, pelayanan, pendayagunaan, pendistribusian, monitoring dan evaluasi sampai dengan tahapan pelaporan pengelolaan. Kedua gambar di atas menunjukkan bagaimana ragam proses komunikasi verbal dengan menggunakan berbagai media dilakukan oleh pengelola untuk mengoptimalkan pengelolaan UPZ.

\section{Komunikasi Nonverbal Pengelola UPZ MD}

Komunikasi nonverbal merupakan bentuk komunikasi yang paling mendasar dalam komunikasi bisnis. Walaupun pada umumnya komunikasi nonverbal memiliki sifat kurang terstruktur sehingga sulit untuk dipelajari, seperti memahami dalam penggunaan bahasa isyarat, ekspresi wajah, gerakan tubuh, sandi, simbol-simbol, warna dan intonasi suara. Dalam penyampaiannya, komunikasi verbal dan komunikasi nonverbal memilki arti yang berbeda-beda, seperti dalam komunikasi nonverbal. Pesan yang disampaikan biasanya dilakukan secara spontan tanpa memiliki rencana dan dilakukan secara tidak sadar dan bersifat alami.

Adapun Komunikasi Nonverbal memiliki beberapa tujuan yaitu: 1). Menyediakan dan memberikan informasi; 2). Mangatur alur suatu percakapan; 3). Mengekspresikan emosi; 4). Memberi sifat dan melengkapi, menentang atau mengembangkan pesan-pesan verbal; 5). Mengendalikan atau mempengaruhi orang lain; 6). Mempermudah tugas-tugas khusus. Komunikasi verbal (verbal communication) merupakan salah satu bentuk komunikasi yang disampaikan kepada pihak lain melalui tulisan (written) dan lisan (oral). Contohnya adalah membaca majalah, mambaca surat kabar, mempresentasikan makalah dalam suatu acara seminar dan lain-lain.

Komunikasi non verbal karena berkaitan dengan unsur gestural, proksial dan paraksemikal para pengelola, maka akan terlihat ketika melakukan pelayanan kepada muzakki dan mustahik. Berdasarkan observasi, penulis mendapati beberapa proses pelayanan yang dilakukan oleh para pengelola UPZ MD berdimensi etis dan moral. Bahkan hal ini ditegaskan dalam SOP UPZ MD dimana, pengelolaan berorientasi pada pelayanan prima (SOP MD, 2018: 23). Adanya visi, misi, dan maklumat pelayanan UPZ MD yang ditempelkan di tempat terbuka menunjukkan bagaimana para pengelola memperhatikan proses komunikasi verbal pada para pengguna. Prinsip kerja yang tertera dalam SOP UPS MD yakni efektif-efisien, tanggung jawab, kualitas, persamaan, kesederhanaan dan kesinambungan merupakan bagian dari upaya untuk menjaga dan memelihara pelayanan. Dalam perspektif manajemen komunikasi, hal ini dinamakan dengan komunikasi non verbal pengelola UPZ. 
Gambar 3. Proses pelayanan Pengelola UPZ MD

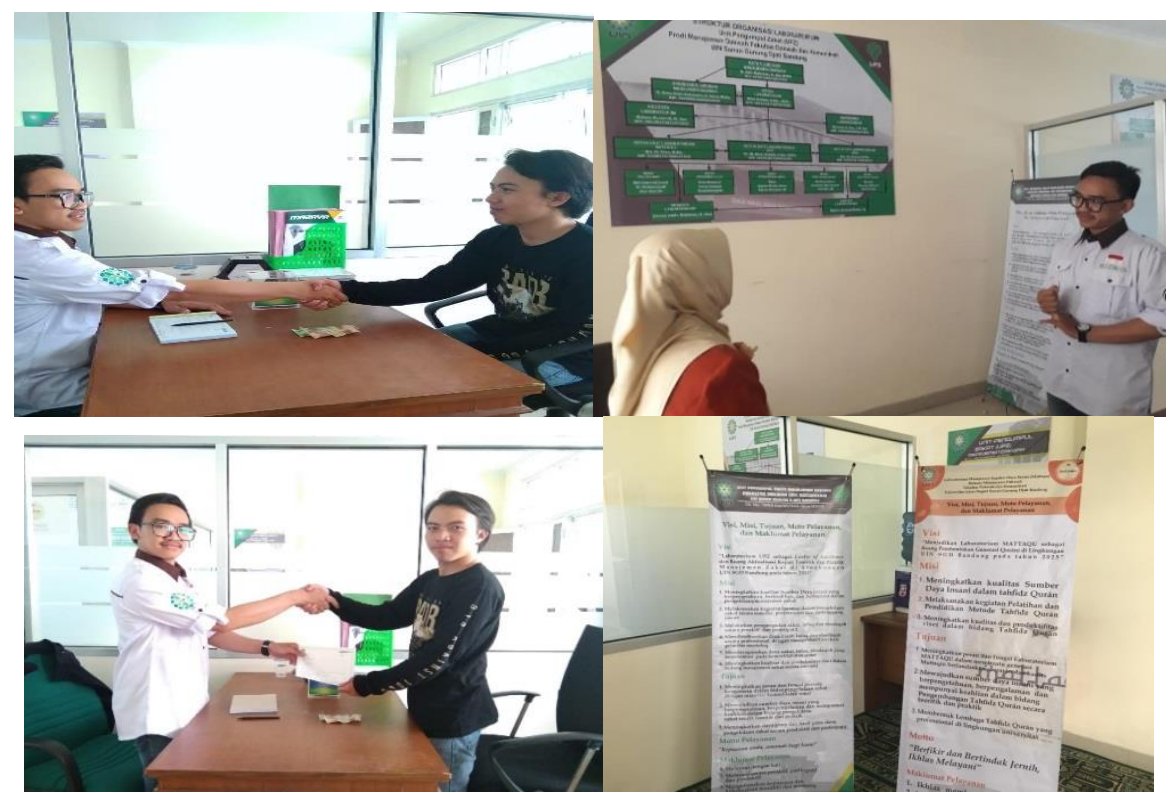

Sumber : UPZ MD, 2018

Gambar 3 merupakan penerapan prinsip kerja UPZ MD yang berorientasi pada pelayanan prima. Penerapan ini dilakukan dengan menegaskan adanya maklumat dan moto pelayanan untuk memberikan kepuasan kepada pengguna. Proses pelayanan ini adalah bagian dari manajemen komunikasi non verbal pengelola UPZ untuk memberikan pelayanan prima bagi pengguna.

\section{Proses Informing melalui Kegiatan Rapat dan FGD Pengelolaan}

Secara operasional, beberapa penerapan manajemen komunikasi UPZ Manajemen Dakwah untuk mencapai tujuannya. Pertama dalam aspek informing, UPZ MD melakukan sosialisasi pengelolaan zakat kepada pengurus inti, mahasiswa dan dosen MD serta seluruh donatur (muzakki) yang mempercayakan penitipan zakat, infaq dan shodaqoh melalui UPZ MD. Pada tahap informing ini, para pengelola UPZ melakukan berbagai rencana strategis untuk membekali para pengelola tentang pengetahuan dan kecapakan pengelolaan zakat, infaq dan shodaqoh. Secara teknis, tahapan informing dalam manajemen komunikasi pengelola zakat di UPZ MD dilakukan melalui rapat pengurus inti yang rutin dilaksanakan setiap satu minggu sekali; Focus Group Discussion (FGD) mengenai aspek penghimpunan, pengelolaan, pendayagunaan dan pemberdayaan dana Zakat, Infaq, Shodaqah (ZIS) secara berkala dan berkesinambungan; Lokakarya dan seminar pengelolaan Zakat, Infaq, Shoqaqoh (ZIS) secara normatif dan produktif; Distribusi dana ZIS melalui beasiswa pendidikan dan 
donasi korban bencana alam; serta Studi lapangan dengan mengunjungi lembaga zakat dan/atau lembaga filantropi Islam.

Gambar 4. Rapat Rutin Pengelola UPZ sebagai proses Informing

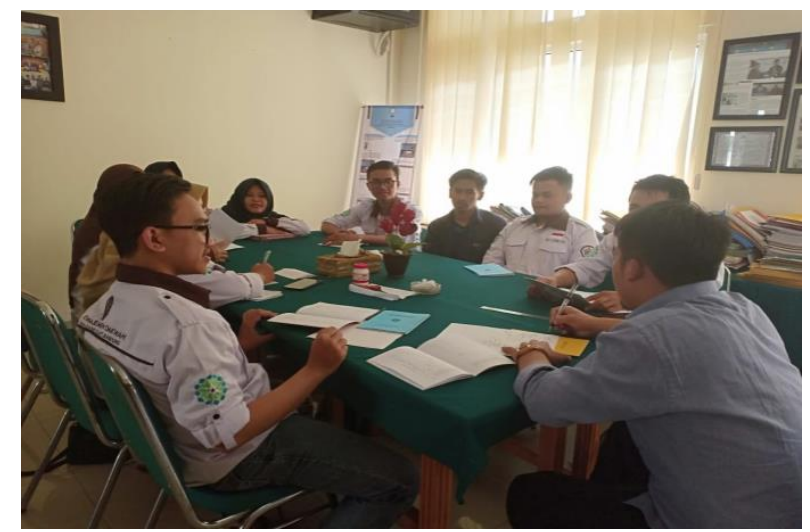

Sumber : UPZ MD, 2018

Gambar 4 di atas, menunjukkan bagaimana proses informing dilakukan secara berkala melalui kegiatan rapat rutin untuk memetakan visi dan misi UPZ Manajemen Dakwah dalam proses pengelolaan zakat, infaq dan shodaqoh. Rapat rutin ini dilakukan dengan melibatkan unsur dosen sebagai penanggungjawab utama dan mahasiswa sebagai pelaksana operasional pengelolaan.

\section{Rekruitmen Pengelola dan Brand Imaging Pengelolaan sebagai Proses Persuading}

Kedua, pada aspek persuading, dilakukan melalui rekruitmen pengelola UPZ MD secara rutin dan berkala. Rekruitmen pengelola ini dilakukan secara khusus untuk seluruh mahasiswa Jurusan Manajemen Dakwah, Fakultas Dakwah dan Komunikasi UIN Sunan Gunung Djati Bandung. Pada tahapan ini, rekruitmen pengelola dilakukan melalui mekanisme dan prosedur tertentu yang telah disepakati. Misalnya, pada tahapan awal, rekruitmen dilakukan melalui sosialisasi keberadaan UPZ MD kepada seluruh mahasiswa jurusan MD. Kegiatan sosialisasi dilakukan baik pada pada masa orientasi mahasiswa baru atau melalui kegiatan yang bersifat eventual seperti seminar dan diskusi publik tentang perzakatan. Sosialisasi dilakukan juga dengan melibatkan dosen pengampu mata kuliah Manajemen Zakat, Infaq dan Shodaqoh (ZIS) serta pengelola jurusan dari mulai ketua jurusan, sekretaris jurusan sampai dengan staf jurusan. Setelah itu, mahasiswa diharuskan melakukan pendaftaran yang disediakan melalui google form, pada tahap ini pemanfaatan media komunikasi digital (internet) sudah mulai 
L. Yulianti

dilakukan untuk mempermudah proses persuasi. Bagi calon pengurus/pengelola yang sudah terdaftar, tahapan selanjutnya diharuskan untuk mengikuti proses pemagangan dalam jangka waktu 6 bulan s/d 1 tahun. Setelah proses magang diikuti, maka ditetapkanlah sebagai pengelola atau pengurus inti.

\section{Gambar 5. Kegiatan Sosialisasi UPZ MD sebagai proses Persuading}
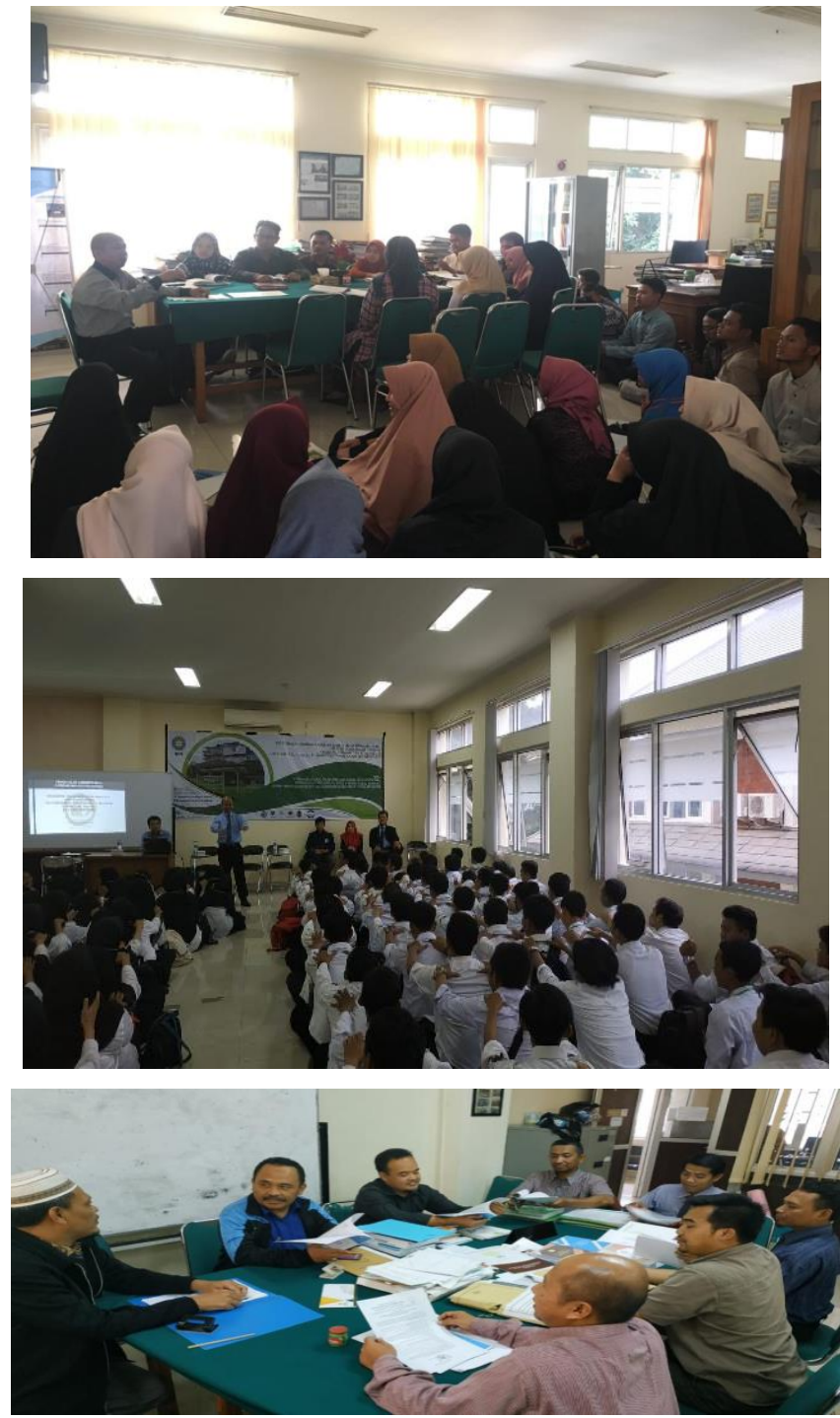

Sumber : UPZ MD, 2018

Gambar 5 di atas adalah FGD sekaligus sosialisasi laboratorium UPZ MD di lingkungan jurusan yang diperuntukkan bagi dosen dan mahasiswa. Dalam proses persuading, manajemen komunikasi ini dilakukan sebagai upaya 
menguatkan eksistensi UPZ MD secara internal di jurusan Manajemen Dakwah.

Selain itu, tahap persuading dalam manajemen komunikasi pengelola zakat UPZ MD dilakukan pula melalui pengenalan brand image program penghimpunan, pendayagunaan dan distribusi dana ZIS. Dalam konteks ini, UPZ MD mempunyai program penghimpunan yang disebut SAJADAH (Sabaraha wae Jadi Ibadah), JUS KOIN (Jum'at Satu Koin), dan Koropak Keliling di setiap kelas di jurusan MD. Program pendayagunaan meliputi Bantuan Wirausaha Mahasiswa dan Beasiswa Pendidikan Mahasiswa. Program distribusi meliputi CINTA YATIM dan Bantuan Sosial Kemasyarakatan terutama bagi korban bencana alam. Brand Image program UPZ MD tersebut disebarkan baik secara langsung melibatkan pengelola, mahasiswa dan dosen di lingkungan jurusan MD maupun melalui media komunikasi seperti instagram, facebook dan media komunikasi lainnya.

\section{Perumusan SOP sebagai Pemetaan Collaborating}

Ketiga, aspek collaborating, dilakukan melalui pembagian peran, tugas dan kewajiban masing-masing stakeholders yang tergabung di UPZ MD. Pembagian peran, tugas dan kewajiban ini ditegaskan melalui perumusan Standar Operating Procedure (SOP) UPZ MD yang disahkan oleh Ketua Jurusan Manajemen Dakwah pada tahun 2018. Pada tahap collaborating, UPZ MD memetakan berbagai proses komunikasi organisasi yang dapat dijalin dalam upaya mencapai tujuan UPZ. Secara organisasi, pengelolaan UPZ MD dilakukan dengan melibatkan dua unsur pengelolaan, yakni dari unsur jurusan dan dosen tetap di lingkungan MD dan unsur mahasiswa. Hal ini disebabkan posisi UPZ MD selain sebagai unit pengumpul, juga diposisikan sebagai laboratorium mahasiswa. Maka pengelolaannya dilakukan dengan melibatkan unsur dosen dan mahasiswa. Secara teknis, dosen tetap yang ditunjuk sebagai pengelola oleh jurusan bertindak sebagai penanggung jawab utama bagaimana proses praktik manajemen ZIS dapat dilaksanakan sebagaimana yang direncanakan. Sedangkan unsur mahasiswa diposisikan sebagai unsur pelaksana teknis atau manajemen operasional yang melakukan fungsi dan tugas UPZ sebagai penghimpun, pendayaguna, pendistribusi dan pemberdayaan dana ZIS di lingkungan jurusan Manajemen Dakwah.

Gambar 6. Perumusan SOP dan Panduan Praktikum Manajemen ZIS sebagai proses collaborating UPZ MD 

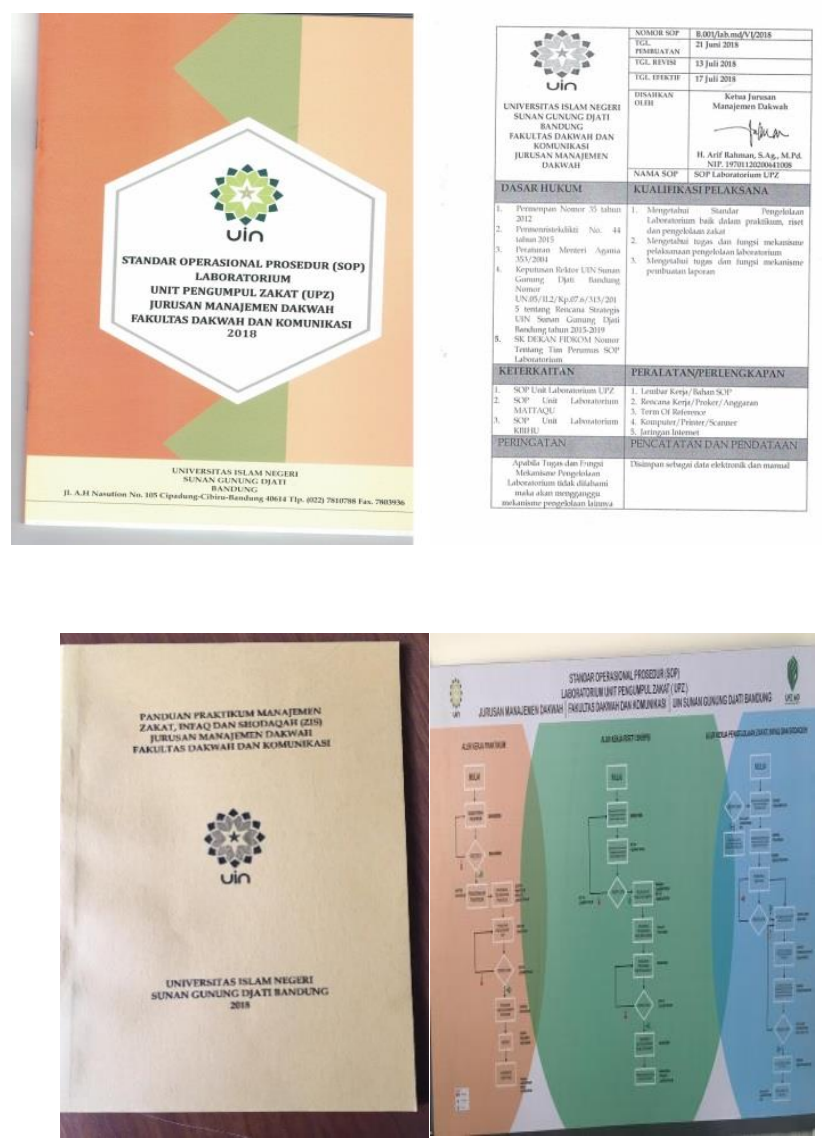

Sumber : UPZ MD, 2018

Gambar 6 di atas menunjukkan bagaimana pembagian peran, tugas dan fungsi dilakukan sebagai bagian dari manajemen komunikasi pengelola UPZ MD dalam tinjauan strategi HRD. Adanya SOP, Panduan Praktikum dan Alur Labororium UPZ MD memudahkan setiap unsur dalam pengelolaan UPZ MD berperan dan berpartisipasi secara aktif. Selain itu, kolaborasi dilakukan tidak hanya antar pengurus operasional mahasiswa saja, melalui SOP itu dirumuskan bagaimana pembagian tugas antara dosen pengelola dengan mahasiswa yang ditunjuk sebagai pelaksana secara operasional. Hal ini dibuktikan dengan adanya struktur organisasi yang melibatkan antara pengelola jurusan MD, dosen dan mahasiswa.

Gambar 7. Struktur Organisasi UPZ MD sebagai proses collaborating 


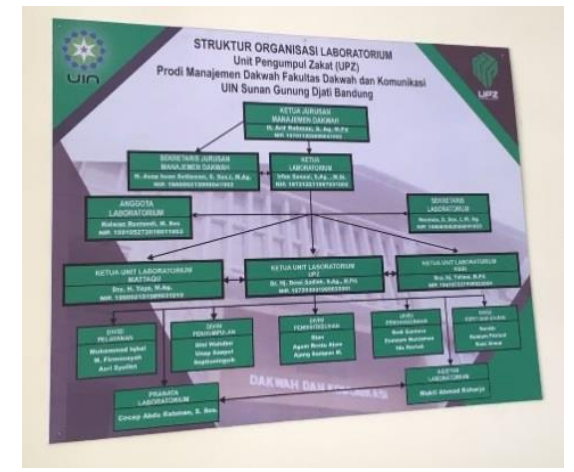

Sumber : UPZ MD, 2018

Gambar 7 menunjukkan secara tegas garis komando, instruksi, jaringan komunikasi dan proses kolaborasi antar berbagai stakeholders di jurusan Manajemen Dakwah dalam pengelolaan UPZ. Struktur organisasi ini untuk mempertegas manajemen komunikasi UPZ MD dalam membangun tim kerja, merumuskan peran dan fungsi serta melaksanakan tujuan pengorganisasian yang dikehendaki untuk mengoptimalkan pengelolaan dana ZIS di lingkungan jurusan Manajemen Dakwah.

\section{PENUTUP}

Human Resources Development dapat diartikan sebagai sebuah proses perekrutan, pelatihan, pendidikan pegawai yang dilakukan oleh sebuah perusahaan untuk memberikan pemahaman mengenai informasi perusahaan kepada pegawai sehingga pegawai memahami tugas dan peran tanggung jawabnya. HRD pun bisa diartikan sebagai sebuah strategi komprehensif dalam sebuah pengelolaan organisasi perusahaan. Tujuannya adalah menciptakan kualitas dan kredibilitas pegawai yang memiliki kecerdasan holistik. HRD mempunyai orientasi dalam mencapai tujuan komunikasi manajemen, yakni: pertama, strategi HRD dapat dilakukan dalam rangka melaksanakan tujuan informing perusahaan. Peningkatan kapasitas pegawai dari tahapan rekruitmen, seleksi dan penetapan kerja merupakan proses yang dilakukan untuk memilih pegawai agar memiliki kemampuan yang diinginkan perusahaan, sekaligus perusahaan memberikan informasi mengenai tujuan, sistem, strategi, pelayanan dan budaya perusahaan kepada pegawai. Kedua, tujuan persuading. Ialah bahwa perusahaan melakukan diseminasi mengenai informasi produk perusahaan. Ketika HRD melaksanakan tugas perekrutan dan pelatihan pegawai, ada titik penekanan mengenai apa yang harus dilakukan pegawai dalam rangka menyebarkan produk perusahaan, propaganda brand image perusahaan, promosi 
perusahaan, dan lain-lain. Dan ketiga, tahapan collaborating. Bahwa melalui rekruitmen, seleksi, pelatihan, pembagian manajerial, penciptaan iklim dan budaya kerja, menjelaskan bahwa perusahaan telah melakukan tujuan kolaborasi. Salah satu fungsi HRD adalah untuk membentuk teamwork yang bisa diandalkan perusahaan. Teamwork akan terwujud ketika telah dilakukan analisis kerja dan pembagian wilayah kerja. Artinya, dilakukan melalui kolaborasi potensi dan kekuatan perusahaan agar tujuan perusahaan tercapai.

Unit Pengumpul Zakat (UPZ) Manajemen Dakwah dalam proses manajemen komunikasi pengelolanya dilakukan melalui dua bentuk, yakni komunikasi verbal baik secara lisan dan tulisan, maupun komunikasi non verbal dalam bentuk gestural, proksimik dan paramikal dalam proses pelayanan mustahik dan muzakki. Manajemen komunikasi ini dilakukan melalui penerapan strategi HRD yang meliputi, aspek informing dilakukan melalui transmisi pesan atau informasi kepada pengelola baik dalam rapat rutin, FGD, maupun kegiatan seminar publik. Persuading yang dilakukan dengan memanfaatkan berbagai media komunikasi seperti buku, spanduk, banner dan media digital (instagram dan facebook). Collaborating dalam bentuk pembagian peran, tugas dan kewajiban yang dirumuskan ke dalam Standar Operating Procedure (SOP).

\section{DAFTAR PUSTAKA}

Anaomi. (2014). Strategi Komunikasi Persuasif Human Resources Development dalam Menyelesaikan Konflik Karyawan PT. Dimas Drillindo Cabang Duri Provinsi Riau, dalam Jurnal FISIP, 1(2), 1-13.

Budiata, I.K.,\& Lasia, I.K. Strategi Pelayanan Prima di Laboratorium Jurusan Pendidikan Fisika FMIPA UNDIKSHA SINGARAJA, ejournal. undiksha.ac.id, 2014 : 2, diunduh pada 30 Juni 2018.

Effendi, M.R.M. (2013). Presentasi power point Komunikasi Bisnis.

Herman. (2017). Strategi Komunikasi Pengelola Zakat, Infaq dan Shodaqoh (ZIS) melalui Media Sosial, dalam Communicatus, 1(2), 171-190.

Huda, N., \& Sawarjuwono, T. (2013). Akuntabilitas Pengelolaan Zakat Melalui Pendekatan Modifikasi Action Research, dalam Jurnal Akuntansi Multiparadigma, 4(3), 376-388.

Jihad, M.Z. (2010). Human Resources Development Based on Competence, dalam Jurnal FISIP, 1(2), 150-158.

Kamal, S. (2016). Urgensi Strategi Promosi dan Model UPZM dalam Menggali Potensi Zakat di Aceh, dalam j-EBIS, 2(2), 1-13.

Katz, D., \& Kahn, R.L. (1966). TheSocial Psychology of Organizations 2ed. Canada: John Wiley \& Sons, Inc.

Khatijatusshalihah. (2016). Exploring The Strategic Role of Human Resources Development in Capacity Building, dalam Psikoislamedia, 1(2), 360-371. 
Rahim, S., \& Syahrullah. (2017). Pengelolaan Zakat Perusahaan dalam Jurnal Akuntansi Multiparadigma, 8(1), 200-215.

Rosadi, A. (2015). Kontekstualisasi Pengelolaan Zakat Umat, dalam Asy-Syariah, 17(1), 1-8.

Saputro, A.D., \& Rois, A.K. (2017). Peran Manajemen Sumber Daya Insani: Kajian di BAZNAS Ponorogo, dalam Al-'Adalah, 14(1), 181-224.

Setiawan, A.I. (2015). Budaya Organisasi dalam Lembaga Islam, dalam Anida, 14(2), 341-355.

Setiawan, A.I. (2012). Dakwah Berbasis Pemberdayaan Ekonomi dan Peningkatan Kesejahteraan Mad'u, dalam Ilmu Dakwah, 6(2), 347-362.

Sincic, D., \& Vokic, N.P. (2007). Integrating Internal Communication, Human Resources Managenement, and Marketing Concept into the New Internal Marketing Phiosophy. Croatia : University of Zagreb.

Sosiawan, E.A. (2009). Model Manajemen Komunikasi dan Administrasi Back Office E-Government sebagai Media Pelayanan Publik, dalam Jurnal Ilmu Komunikasi, 7(1), 67-83. 
L. Yulianti

Tadbir: Jurnal Manajemen Dakwah Vol. 3 No. 2 (2018) 103-122 